\title{
Hate crime, policing, and the deployment of racial and cultural diversity
}

OÑATI SOCIO-LeGAL SERIES Volume 10, Issue 6 (2020), 1193-1213: GOVERNiNG THE POlitiCAL: LAW AND THE POLITICS OF RESISTANCE

DOI LINK: HTTPS://DOI.ORG/10.35295/OSLS.IISL/0000-0000-0000-1129

RECEIVED 24 SEPTEMBER 2019, ACCEPTED 08 SEPTEMBER 2020

\section{TIMOTHY BRYAN*}

\section{Abstract}

This paper examines how diversity is mobilized and deployed as a form of hate crime response in the York Regional Police Service, and how commitments to racial and cultural diversity embedded in the framework of hate crime policy are interpreted by police officers engaged in the frontline policing of hate crimes. Hate crime policies and specialized training programs in Ontario were developed around two central foci: 1) traditional policing concerns involving proper investigative techniques, evidence collection, documentation, and officer roles and responsibilities; and 2) emerging concerns regarding victim care, community relations, and commitments to racial and cultural diversity. Drawing on interviews with officers stationed at all five of the Service's divisional locations, this paper shows how commitments to diversity embedded in the Service's approach to hate crime exist along-side, and in conflict with, officer perceptions that see diversity as a source of the problem of hate.

\section{Key words}

Hate crime; policing; race and diversity

\section{Resumen}

Este artículo examina la forma en que se moviliza y despliega la diversidad como una forma de respuesta a los delitos de odio en el servicio de policía regional de York (Canadá), y la forma en que el compromiso con la diversidad racial y cultural, que forma parte del marco de la política sobre delitos de odio, es interpretado por los miembros de

\footnotetext{
* Tim Bryan (Dalhousie University) is a sociologist and socio-legal scholar whose primary research interests involve the policing of hate crime, race and racism, Canadian multiculturalism and criminal justice in Canada. Dr. Bryan's current research examines the policing of hate crime by municipal police services, particularly the way commitments to racial and cultural diversity, and efforts to improve police-community relations inform the intervention strategies of police. Dr. Bryan has conducted policy research for the Ontario Association of Chiefs of Police on law enforcement efforts to combat hate crime in Ontario, and has presented his findings to municipal police services in Ontario. Email address: t.bryan@dal.ca Dalhousie University, Halifax Nova Scotia, Canada, B3H 4R2.
} 
la policía que están en primera línea de la lucha contra los delitos de odio. Las políticas y entrenamientos especializados sobre delitos de odio en Ontario se desarrollaron alrededor de dos focos principales: 1) la preocupación tradicional de la policía por las técnicas apropiadas de investigación, la recolección de pruebas y documentación y los roles y responsabilidades de los y las policías; y 2) nuevas preocupaciones acerca del cuidado de las víctimas, las relaciones sociales, y el compromiso con la diversidad racial y cultural. Partiendo de entrevistas con miembros de la policía destinados en las cinco divisiones del Servicio, el artículo muestra cómo el compromiso con la diversidad inserto en el abordaje policial al delito de odio existe en paralelo y en conflicto con las percepciones de los y las policías de la diversidad como fuente del problema del odio.

\section{Palabras clave}

Delitos de odio; labor policial; raza y diversidad 


\section{Table of contents}

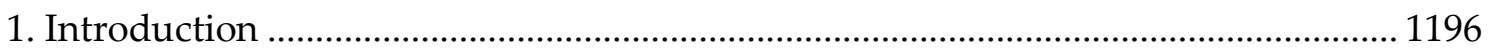

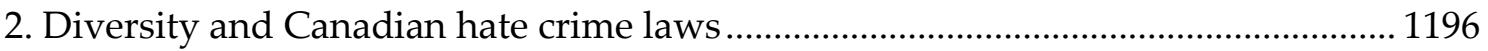

3. Diversity as police work and diversity as hate crime prevention ............................. 1199

4. Diversity contested: police as victims of the community ........................................... 1204

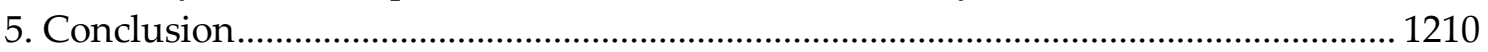

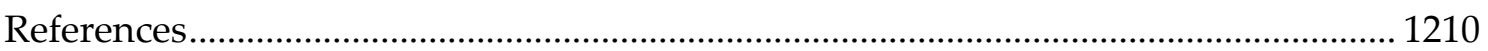




\section{Introduction}

This paper examines how diversity as both a discourse in police policy and a commitment of police work, is mobilized and deployed as a form of hate crime response in the York Regional Police Service (YRPS), and how commitments to racial and cultural diversity embedded in the framework of hate crime response are interpreted and deployed by police officers engaged in the frontline policing of hate crimes. Drawing on 20 interviews with officers stationed at all five of the Service's divisional locations and officers working in the Service's Diversity Equity and Inclusion Bureau (DEIB), I show how commitments to diversity embedded in the Service's approach to hate crime exist along-side, and at times in conflict with, officer perceptions of diversity as a source of the problem of hate. ${ }^{1}$ Building theoretically from critical race critiques of diversity and multiculturalism frameworks, I suggest that the very framework of diversity, which is premised largely on recognizing and celebrating difference, allows for, and at times contributes to, an institutional blindness to issues of inequity and structural violence. This article, therefore, examines the deployment of diversity as it is enmeshed in organizational practice and reveals the precarious, and at times, contentious, presence of commitments to the conceptions of diversity within institutional policy and by institutional actors supposedly committed to its advancement.

In the introduction of this essay, I outline the legal framework governing hate crime in Canada and the broader commitments to racial and cultural diversity around which policing in Ontario is organized. In sections two and three, I detail the organizational structure of the YRPS and its DEIB and explain the way diversity informs police/community engagement approaches and hate crime response. In section four, I examine the way diversity is resisted, contested and questioned by some officers engaged in that very work of responding to and investigating hate crimes. I show how narratives of 'police victimization' that position diverse communities as threats to police safety, and perceptions that hate crime laws are a form of preferential treatment for minority communities, contrast with the stated commitments of the Service.

\section{Diversity and Canadian hate crime laws}

The term "diversity" has been used to refer to a broad range of techniques, practices, outcomes, strategies and goals within and outside law enforcement settings (Stout 2010, Rowe 2012). Often linked to the need for greater tolerance, acceptance, and sensitivity, the language of diversity has framed policies designed to transform law enforcement on the inside - by increasing representation from under-represented communities within the ranks of police services; and reframe the approach and image of policing on the outside - by responding to diverse communities in ways deemed more culturally appropriate. In many law enforcement contexts creating a more diverse workforce has been achieved through changes in hiring practices designed to attract and retain

\footnotetext{
${ }^{1}$ I have intentionally not provided information that would be helpful in contextualizing the information provided by respondents such as official titles and divisional locations. This decision was made in sections where divulging this information risked disclosing the identity of respondents. I have also changed gender pronouns in some sections to prevent disclosing the identity of officers, therefore male respondents are not always identified by the pronoun "he" and female respondents are not always identified by the pronoun "she".
} 
candidates from a wider range ethno-cultural backgrounds and by incorporating cultural sensitivity or cultural awareness, and equity and inclusion type programing traditions into police training curriculum (Kazarian et al. 2007, Stout 2010, Rowe 2012, Henry et al. 2017). Diversity therefore, cannot be seen as one set of specific practices but rather a range of activities that attempt to reorient intuitional practices to make them more inclusive.

Over the last several decades, the language of diversity has been applied to particular locations and forms of labour within police services as well. Large urban centers in Canada for example, have formally and informally incorporated diversity to advance the brand of their municipalities. In many of these jurisdictions such as Toronto, Peel Region, York Region and many others, diversity has been incorporated as a type of institutional work. Diversity units also sometimes called race relations or community relations units have been formed in many jurisdictions in Canada. Tasked with doing 'diversity work' - engaging, networking and partnering with the communities to, impart improve (or repair) police relations with communities, law enforcement agencies have also used the language of diversity to describe community policing approaches or community engagement strategies designed to increase positive interactions between police and community members through methods that foster accessibility, transparency, familiarity, and collaborative communication (Griffiths et al. 2001, Tilley 2003). In some jurisdictions in Ontario, for example, municipal police services have established community consultation committees which aim to provide feedback to police in areas of police training, policy and community engagement, or engage with communities through organized sporting events, picnics, cultural festivals and police facility tours (Toronto Police Service Community Consultative Process n.d.).

In 2001 for example, Ontario's Police Services Act (PSA) was amended to require municipal police services to develop and maintain procedures for responding to hate crimes. A number of police services had already developed their own guidelines patterned on guidelines developed by American police forces in the early 1990s, but amendments to the Adequacy Standards Regulation (2016) of the PSA made hate crime a focus for police as outlined by law. Hate crime policies and specialized training programs in Ontario were developed around two central foci: 1) traditional policing concerns involving proper investigative techniques, evidence collection, documentation, and officer roles and responsibilities; and 2) emerging concerns regarding victim care, community relations, and commitments to racial and cultural diversity. As one officer guide to hate crime investigation and prevention states: "An appropriate response to hate/bias motivated crime goes beyond law enforcement and conveys a strong message of respect for, and commitment to, a diverse society" (Ontario Police College 2007, 3).

While the concept of diversity has been incorporated into the official language of law enforcement institutions and many public and private sector organizations, it has been critiqued for the way it frames issues of inequality as problems caused by cultural difference (Day 1998, Bannerji 2000, Ahmed 2000, 2012). Policies and programs designed to foster diversity operate largely through projects of proximity, awareness and exposure whereby differences - imagined largely as cultural or ethnic, are overcome through a process of (cultural) exchange. By encouraging "diverse" and "non-diverse" bodies to "live together", tensions - largely configured as problems of translation, 
communication, understanding, or recognition - that can occur as a result of "difference" can be addressed (Hage 2000, Mackey 2002, Thobani 2007, Haque 2012). Many of these preoccupations are reflected in the design of diversity and community engagement initiatives such as advisory committees, police-community festivals and communitybased training initiatives.

Diversity expressed through the discourse of multiculturalism has allowed states to not only represent themselves as hospitable and welcoming, but to claim diversity as an attribute of national life. Of the use of diversity by organizations, Sara Ahmed (2012) asserts that diversity much like multiculturalism, performs a kind of institutional work. Discourses of, and organizational commitments to diversity, are deployed by institutions, not as remedies to issues of inequality, but to signal that because organizations have embraced diversity, they no longer have problems with diversity. For organizations, the creation of diversity offices, diversity polices or the hiring of diversity experts, function pre-emptively to ward-off potential accusations of institutional racism, or reparatively, to help restore a public image when it is revealed that the organization has failed to live up to its own commitments (Ahmed 2012).

Despite critiques of the frameworks of diversity, the discourse of diversity remains central to law enforcement in Ontario. The impact of the changing demographic landscape in Ontario on policing - in particular the province's increasing racial and cultural diversity - has, for example, added to the incorporation of diversity and multicultural discourse into the declaration of principles of the Police Services Act which stresses the need to ensure that policing is conducted in a way that is "sensitivity to the pluralistic, multiracial and multicultural character of Ontario society" (Police Services Act, 1990).

Criminal Code provisions pertaining to hate crime in Canada, are in many ways, the result of the extent to which the discourse of diversity in the form of Canadian multiculturalism, has become a mainstream national ideology. "Hate" as an object of criminal justice attention first came to the fore following the Report to the Minister of Justice of the Special Committee on Hate Propaganda (1965), commonly referred to as the Cohen Report. This concern emerged largely as a result of the emergence of an international human rights framework, which became a prominent focus nationally and internationally in the wake of the Second World War, and the establishment of a multiculturalism in Canada. Canadian society. The Cohen Report was instrumental in redefining hate propaganda as a threat to Canadian society. The report stated that while the extent of the problem of the promotion of hate was limited in Canada, "individuals and groups promoting hate in Canada constitute 'a clear and present danger' to the functioning of a democratic society. For in times of social stress, such 'hate' could mushroom into a real and monstrous threat to our way of life" (Cohen Report, 24). The Cohen Report's recommendations ultimately lead to Sections 318-320 of the Canadian Criminal Code which criminalizes advocating genocide (Section 318.1), public incitement of hatred (Section 319.1) and willful promotion of hatred (Section 319.2). Since the 1960s, two other significant provisions were added to the criminal code designed to respond to hate crime: Section 718.2(a)(i), which increases sentences based on evidence that an offender was motivated by "hate, bias or prejudice," and Section 430(4.1) which criminalizes mischief to religious property. Together, these provisions of the Criminal 
Code, provide the basis for criminal justice sanctions for hate crime and set the foundation for police response.

\section{Diversity as police work and diversity as hate crime prevention}

York Region is a municipality located north of Toronto and is home to 1.1 million residents (Statistics Canada 2016). The Region claims to be one of the most diverse in Canada with numerous racial, cultural, and religious communities calling the Region home. York Regional Police Service's (YRPS) hate crimes unit is located within the service's Diversity Equity and Inclusion Bureau (DEIB) and is one part of the Service's 2,000 member police force. The DEIB's mandate is to build bridges and develop community partnerships that promote community safety and ensure that the Service "properly meets the needs of [its] global community which is enriched by the linguistic, religious and ethno-cultural diversity of community members" (York Regional Police 2016b). Organizationally the bureau is attached to executive services which reports directly to the Chief of police and is composed of four sections: 1) Diversity and Cultural Relations, 2) the Hate Crime Unity, 3) Diversity Equity and 4) Inclusion Specialist and the service's chaplaincy program.

The Diversity and Cultural Resources Branch engages in work that involves building relationships with the region's diverse communities through celebration, education, and outreach. This branch organizes annual police-community events such as the Service's Black History Month Celebrations, Asian Heritage Month events, International Day for the Elimination of Racial Discrimination, Houses of Worship Tours, and its Diversity Speaker Series² (York Regional Police 2016b).

The Hate Crime Unit forms the investigative arm of the Bureau and is responsible for overseeing and monitoring the investigation of hate crimes, which are investigated in the Service's five divisional offices spread throughout the region. The unit also hosts quarterly meetings to provide training and to facilitate information sharing between the Service's 21-member hate crime team. This unit also co-ordinates and conducts hate crime awareness campaigns such as its 2016 Say No to Hate advertising campaign on the York Regional Transit system. YRPS's Chaplaincy program is also housed under the DEIB. There are eight chaplains who represent the area's five largest faith communities. They not only meet the spiritual needs of the Service but also act as liaisons between YRPS and its region's religious communities.

A Diversity Inclusion and Equity Specialist (DEIS), whose role is to promote diversity and eliminate barriers to inclusion within the Service, is also attached to the Bureau. The DEIS promotes diversity through program development, training, and the creation and implementation of self-assessment tools. Internal support networks include volunteerorganized and driven associations that provide YRPS personnel with the ability to network with individuals sharing similar goals. Although each component of the DEIB holds a different mandate and is charged with different responsibilities, they often collaborate - formally and informally, and pool resources on initiatives of mutual interest. Within this institutional set-up, hate crime response and public outreach are

\footnotetext{
2 From December 2014 to September 2016, I attended three of YRPS's hate crime team meetings, a YRPS sponsored citizenship ceremony, a Black History Month Celebration organized by the Service, and a Houses of Worship Tour.
} 
viewed as complementary approaches to defending and celebrating diversity. Both the discourse of diversity and diversity type practices as a means of policing allow the Service to not only be in compliance with the larger framework of policing in Ontario, but as also builds community contacts that are potentially useful in criminal investigations or in intelligence gathering efforts.

When I spoke to a senior officer in the DEIB, he described the Bureau's approach to hate crime and diversity work as one anchored in human rights and the practice of two-way communication. Both institutionally and rhetorically, diversity and diversity work set the stage for hate crime response. The officer described the DEIB approach to diversity and hate crime as follows:

When you look at what we call diversity, where we honour and celebrate and showcase, where we celebrate all of the wonderful attributes of human diversity, we call that diversity. We also say that when we look at hate crime, it's a violation of that (...). So, if you are targeted because of your core identity, because of who you are, something that you have no control over, this is who you are, this is your identity. When people target you criminally, that is a violation of human rights. (Resp. 3)

Advocates have argued that increased sentences for crimes motivated by hate allow states to make a "public statement" that bias-motivated crime is legally and socially unacceptable, thus reaffirming national commitments to equality and human dignity (Perry 2001, Iganski 2002, Chakraborti 2010, Chakraborti and Garland 2010). Not only do hate crime laws punish individual criminal behaviour, they are symbolic or expressive of larger aims to protect individual rights and promote national inclusion. Canadian criminologists Julian Roberts and Ross Hastings (2001) maintain that hate crime provisions are an expression of social disapproval, and as such, are vitally important in a multicultural society. Since criminal law plays a very important role in "demarcating the boundaries between acceptable and unacceptable conduct," as Martha Shaffer (1995) notes, "the criminal law plays a normative or symbolic role in instructing citizens about the types of conduct that give rise to social disapprobation" (Shaffer 1995, 212). As "gate-keepers" to the criminal justice system who exercise a high degree of discretion, police decision-making is vital to the successful enforcement of hate crime previsions (Boyd et al. 1996, Bell 2002, Hall 2012).

Policing procedures tethering diversity to hate crime response through concerns about protecting human rights, building community trust, and maintaining public safety, work to make diversity a type of law enforcement practice. Employing practices that respect diversity functions as a method of effective policing, allowing police the ability to meet the needs of communities and fulfill their mandates of bringing police and communities together.

When I spoke to Diversity Officers, they told me that their work involved meeting people. These officers conducted a range of activities. They regularly attended Welcome Centres that connect newcomers to community services, delivered information and public awareness presentations, attended community celebrations, and conducted houses of worship tours, all of which are designed to promote understanding of the diverse religious traditions of the region to YRPS officers. Despite the wide range of activities diversity officers perform, diversity work, I was told by officers, was about sensitivity and understanding, and avoiding missteps that could jeopardize a positive 
future relationship. One officer described the importance of positive interactions with the public and conflicts that can arise. "The biggest thing is minding your P's and Q's," the officer noted.

Just because, for one, you don't want to offend anybody and initially that was my biggest fear. There are so many different religions, so many different people with so many cultural backgrounds and you are always on that fine line of making sure that you're not offending anyone by saying something because, you know what I mean, it's a relationship you are trying to build. (Resp. 23)

In the above officer's narrative, diversity work requires positive interactions because it also involves connecting with communities and forging new relationships. These connections provide opportunities to encounter communities for the first time, or to push positive relationships forward. This could be done by supporting community events with police presence according to the same officer, in a tangible sign of police commitment to community engagement according to police. A senior officer in the DEIB stressed that for police to form lasting connections with communities, they need to use "every opportunity" to get to know and understand community concerns.

You will never obviously understand all of the intricacies but it is important to know who the communities are, who are the ones that are impacted, what's the source of them being impacted negatively by hate crime, what are some of the threats to the community, what are some of the challenges they face, how can we use our services or even enhance our services to work specifically with groups of people. (Resp. 3)

Being sensitive to the traditions of diverse groups and attempting to understand where people are coming from occurs through exposure and interaction. By knowing your community and by initiating contact with communities, police are better able to serve community. The same senior officer remarked about the reputation of the diversity unit within the Service. He told me that some officers described the Bureau's work as the, "the samosa and sari syndrome" expressing the perception among some officers in other units that the diversity work is not real police work (Resp. 3). This perception I was told, impacted the credibility of the unit's work as "police work" and at times impacted the unit's ability to attract candidates for vacant positions. Despite the negative view some officers hold of the work the Diversity Unit does, he insisted that these meetings were important for cementing policy/community ties.

But sometimes you need to do those things in order to get to some of the deeper issues. You need to make small talk, you need to attend events, and just as communities support us in the work that we do, so too do we need to reciprocate that support. (Resp. 3)

For officers, sensitivity becomes a method of community engagement. Police can address longstanding concerns about their interaction with diverse communities as they get to know the communities they serve. Knowledge and interaction make service delivery relevant to communities at the same time that they improve police-community relations. Officers within the Bureau relayed their experiences at community organized events and the efforts they go to in order to ensure open communication and positive contact with diverse communities. An officer recounted to me his experience at event where even the mundane exchanging a business card could be an important connection; "When we go to events we have the opportunity to meet with multiple people, we exchange business cards and when we look at all the business cards [at the end of the event] we say 'oh, 
you are part of this organization, can we have a meeting and tell you a little bit more about what we do" (Resp. 3). These meetings, I was told, could lead to invitations to further events and even deeper relationships. "It's up to them whether they want to come or not. Sometimes they will and I take a look at the event and I say, 'oh ok, this is really good, maybe we'll start to bridge those gaps'" (Resp. 3).

Diversity and hate crime response are also connected through community building initiatives. The officers understood hate crime as a form of criminal behavior that, while directed at one particular victim, victimizes entire communities. The officers expressed an understanding of diversity as something forward looking that aims to open-up lines of communication that can be useful in addressing potential future community issues. Community service in the present makes possible police success in the future. A number of officers told me that diversity work and police community partnership play a large role in YRPS's vision of policing.

We serve the community and we need to be a part of the community and we need to engage the community in all areas. That way, when something happens the community feels comfortable and trusts the police in helping them out and investigating crimes. (Resp. 19)

Many officers expressed the role of law enforcement in building-up and protecting diverse communities involves establishing connections and forming positive relations that bring communities and police together. This involves a community-focused mindset in which the police meet with community members on their "turf" as a way of aligning policing with community needs. Through diversity work, which according to police is built on communication, sensitivity, empathy, and understanding, new possibilities are opened-up. Policing and the role of the police officer are re-imagined and centred on community empowerment and community service. Another officer told me that the awareness developed from police engagement with diverse communities was important to reform police mindsets, which results in more effective police service.

The police are the community and the community are the police, and the Police [Services] Act says you have to represent the community that you serve, and it's mandated. So we are duty bound to do that. So I think that may have morphed into the priority of, well, because we're so diverse and people come with their own biases to this country that we have to break those biases down to say we listen to everyone. You get treated, whether you are male or female, you get treated all the same way with respect and dignity. And we go from there. (Resp.16)

Based on this officer's narrative, the diversity frame also works as a form of awareness raising, a method of instructing officers about their community and a reminder of the stakes involved in $21^{\text {st }}$ century policing. Indifference to community voices, therefore, can be dangerous for the reputation of police services and as officers note, refusing to listen to communities is a lost opportunity for police because communities can be valuable sources of information and intelligence. Diversity can become institutionally valuable in the context of solving crime and crime prevention; diversity prevents potential conflict within society by encouraging mutual understanding and sensitivity to individual and collective traditions. By participating in community events, officers are able to see past differences. While traditions, values, and beliefs may look quite different, diversity reminds us, according to officers, that we are all the same and that we are all committed to the goal of living peacefully with one another. 
Recently, YRPS informally rebranded its diversity officers as "hate crime prevention officers" to reflect the link between hate crime and diversity. A high-ranking officer in the unit told me that the relationship between diversity and hate crime could be imagined as two sides of a coin. "On one side of the coin are all of the positive attributes that diversity brings," he stated, "and on the flip side of the coin, when you have human rights violated, you have the rapid response of the hate crime unit" (Resp. 3). Diversity and hate crime response are thus seen as complementary practices to maintaining social cohesion and respect for the law. Diversity, however, is not solely a mechanism of community building or a method of responding to hate crime. I was told that diversity could also be mobilized as a form of hate crime prevention. A senior officer explained to me that hate crime could be understood within a spectrum of discriminatory or violent acts. Some behaviours such as offensive gestures or slurs are lower on the spectrum while others such as genocide, ethnic cleansing and war crimes are at the very top. The officer explained that diversity was connected to hate crime because diversity work helped break down barriers by, in the officer's words, "creating opportunities for education, for learning, for dialogue, for cross cultural understanding for intercultural dialogue, for networking, for connecting to people or different from you" (Resp. 3). Diversity, according to the officer, combats what occurs at the global level as genocide, in the local context. "So all of those things - out reach into communities - and things that break down barriers that's what they advise on the global level. So, what they do on a global level we do in the microcosm, they call it diversity". Mobilizing diversity as a form of hate crime prevention, however, assume the problem of hate crime is a problem of individual attitudes, dispositions, and sensibilities, or as a lack of healthy exposure to diverse individuals and communities.

One senior officer who had immigrated to Canada recounted her thoughts on why people commit hate crimes. She stated that many people in Canada have never experienced living in a country as a foreigner, and so have never developed a sense of empathy for others in different situations; they "fail to understand how other people feel when you make a comment" (Resp. 18). In this formulation, social harmony is a natural product of healthy interactions. It requires an understanding of the hardships and challenges faced by diverse people. In the same way that police interactions with communities are 'reformed' through increased officer sensitivity, so too can individuals if they simply put themselves in someone else's shoes. Here, diversity becomes a response to ignorance and intolerance when mobilized as a form of education. Neighbour disputes, acrimonious work relations, road rage, graffiti, vandalism - all crimes that police officers told me they saw to varying degrees on a regular basis - can be addressed, in their view, through increased diversity. Diversity functions as hate crime response and prevention because it is seen as a framework for promoting mutual understanding. In the context of police response, officers who are able to put themselves in the "shoes of victims" understand their concerns and sympathize with them and are able to more effectively serve victims and solve crimes.

Diversity frameworks are self-referential in the narratives of officers who claim that diversity is important to hate crime response. Hate crime serves as a reminder of the outcome if diversity fails. When diversity fails, hate grows and hate is what lies at the root of intra- and inter-community conflict. Diversity not only provides a set of logics for understanding hate crime, and a method of preventing hate, it furnishes police with 
a vocabulary through which to talk about the problem of hate, often anchored in discourse of Canadian multiculturalism.

\section{Diversity contested: Police as victims of the community}

While diversity is employed as a rationale for hate crime prevention, it was also framed by some officers as the "source of the problem". In my interviews officers alluded to the fact that "too much diversity" could lead to friction and community conflict, the result of which can be hate crime.

Concerns about the effects of multiculturalism on Canadian society were explained by reference to patterns of settlement that have produced distinct racial, cultural, and ethnic communities in and around the Greater Toronto Area (GTA). Ethnically homogenous areas, referred to by some as "ethnic enclaves," have emerged throughout the GTA as a result of immigration patterns, proximity to social and cultural supports, affordability of homes, job opportunities, and the forced relocation of communities due city planning efforts. Many of these areas, such as Toronto's Chinatown, Greektown, and Little Italy, have been rebranded as distinct cultural centres in an effort to promote commerce, boost business, and enhance the city's tourist economy. In the GTA, large Jewish, Chinese, Italian, and Eastern European communities reside in distinct areas across the region. Their presence is quite visible, with multi-lingual storefront signs and cultural and religious centres dotting the landscape. While officially these neighbourhoods are described as part of the cultural make-up of the GTA, some officers interpreted their presence as a sign of cultural insularity and a reflection that Canadian multiculturalism had failed to properly integrate newcomers. One officer described the racial and cultural character of the areas she patrolled and the way immigrants had established communities.

They live in a very condensed area. Once you get north of $16^{\text {th }}$ Ave. there is not a lot of Chinese community north of that, if any. So it's a very tight group. There's the Italian communities in Vaughn. There's a Jewish community in Thornhill, and again, very tight personally and geographically. They all live in these areas, the Russian community as well (...). We have a south Asian community in Markham south of the 407 [expressway] and the Sri Lankan community. Again, pretty much all their friends are Sri Lankan and that's what they identified with. There's no white guy in the group, there's not a black guy in the group that's just the Sri Lankan group. (Resp. 10)

The problem, according to this officer, is that immigrant communities have created neighbourhoods where there is limited contact between themselves and others. This "refusal to spread out" and interact has contributed to insular mindsets. The officer told me that even the mundane aspects life like shopping for groceries or buying a vehicle were conducted within separate spheres. "Many Chinese will only deal with other Chinese and that's where they buy their cars or when they get their groceries or when they do anything it's only with other Chinese. Italians it's very much the same thing. Russians, Russian grocery stores. Jewish, Jewish grocery stores, and so one and so on" (Resp. 10). When I asked what was the greatest challenge of the isolated and insular nature of what this way of living, I was told that the failure to integrate prevented communities from adapting to the Canadian way of life. She told me that some residents of the region had not even mastered English despite the amount of time spent in Canada. 
There are people who have been here 30 years and they can't speak English and they don't know what is outside of their own borders (...). So that's one of the downsides I see to multiculturalism. (Resp. 10)

According to this officer, the lack of diversity in some areas was also attributable where communities chose to settle. Patterns of settlement for immigrant and ethnically and culturally diverse communities were deliberate and calculated, and had implications for the ethnic landscape of the Region. She explained to me that she lived in a very white community that had no "Black people" and "one Asian guy" who operated a local convenience store and suggested that if more communities of colour moved into her neighbourhood the character of the area would have been quite different.

In [location omitted], I think, excluding the policeman that just moved up there, I think we have three or four families and [location omitted] is a very large place. So I just think that's the downside to the multicultural way that we have things set up where everyone lives in these little boxes and no one knows what the other side is doing and we have outsiders looking in and insider's looking out. And you see it in Brampton, these old South Asian guys at the park and there is no interaction, there's never any interaction it seems and that's too bad. (Resp. 10)

Other officer's noted similar concerns about what they perceive as the "downside of Canadian multiculturalism" and the insularity of communities by way of what they claimed were incidents of inter-ethnic conflict. I was told that the Region had seen incidents of gang conflict motivated by ethnic differences. While the officer's comments do not explicitly associate hate crime with a lack of integration, the frame of 'failed multiculturalism' provides an understanding of hate crime that is linked to the lifestyles, behaviours and mindsets of immigrant communities. In the officer's narrative, prejudice, bias or hate experienced by people of colour and recent immigrants is replaced by the 'problem' of failed social integration. Integration is foregrounded in this account because hate crime is seen as the result of a lack of positive exposure to others.

This officer's narratives are similar to discourses in wider circulation that use cultural difference as a prism through which to view current social issues. Discourses of cultural difference have reconfigured contemporary discussions about security in the post-911 world (Razack 2008), the rights of non-Western women (Jiwani 2011), and crime and justice in Canada (Tator and Henry 2006, Chan and Chunn 2014). As Sherene Razack (2008) shows in her analysis of legal and political responses to Muslims during the 'war on terror,' notions of cultural incompatibility with Western values constructed Muslims as "uncivilized" and "barbaric," which made permissible, justifiable, and excusable forms of surveillance and containment. As Alana Lentin (2014) illustrates of contemporary debates about the "failure of multiculturalism" in Europe, criticisms of multiculturalism are increasingly couched in cultural terms (Lentin 2014, 1268). She notes that, in the European sphere, multiculturalism has been treated as the cause of a "whole sway of socio-political problems affecting European countries" (Lentin 2014, 1273). "From crime, to terrorism, to urban segregation," broader social issues are interpreted as the result of "excessive tolerance and benevolence towards disloyal, unassimilable, culturally different others" (Lentin 2014, 1273). Here, the threat to social stability is imagined as a threat from, as Lentin states, "the unintegrated subjects of multicultural tolerance" (Lentin 2014, 1273). 
This frame has at least two important implications. First, concerns about increased hate crime due to the failure of some communities to "integrate" into Canadian life, distorts the empirical reality of hate crime victimization. In 2017 for example, York Region nearly $90 \%$ of all reported hate crimes were motivated by either race or religion with the Jewish, Muslim, Black, and South Asian communities the most targeted (York Regional Police Service 2018). These figures were similar to those released by the Service for 2016 and 2017 (York Regional Police Service 2016b, 2017). While data on the identity of the perpetrators was not available, official data suggests that in reality many of the very communities whose social isolation the officer claims, exacerbates hate crime, are the ones most victimized by hate crime. Secondly, this frame functions to shift responsibility for hate crime onto immigrant communities and communities of colour in ways that deflect from the original concerns that gave rise to anti-hate responses: the actions of white supremacist groups and those advocating racial hatred. ${ }^{3}$ Instead of seeing the need for protection for communities of colour from the very real danger of hate mongers or organized hate groups, communities of colour are urged to live in a way that reduces violence for which they are the primary targets. This re-framing of hate crime as a problem of integration or of the actions of communities of colour, mirrors the way officers spoke about their concerns about police-community relations, particularly with respect Black communities. In August 2014, the fatal shooting of Michael Brown, an unarmed 18-year-old Black male in Ferguson Missouri, sparked massive national protests in major American cities. (Buchanan et al. 2015) A few weeks prior, the chocking death of Eric Garner at the hands of NYPD officers who had been detained by police for reportedly selling illegal cigarettes, made national headlines (Berman 2014). Garner's killing was followed later that year by the fatal shooting of 12-year-old Tamir Rice by police in Cleveland Ohio, and the following year by the shooting death of Walter Scott, shot from behind five times after being stopped in his vehicle for a non-functioning break light (Fitzsimmons 2014, O'Shea 2016).

The reverberations of the police killings of unarmed Black men and the protest action that followed were not contained to the United States as solidarity protest sprung up in Canadian cities as well, but for some officers I interviewed the events in the United States became a prism through with they spoke about their concerns with diverse communities. The Black Lives Matter movement placed police interactions with the public, and with Black communities in particular, in the spotlight, and demanded comprehensive reform of policing and a recognition of the racialized nature of criminal justice. Many within the law enforcement community have treated these demands as personal attacks against law enforcement and an example of the smearing of the reputations of good police officers that is taking place across North America. In the words of one officer interviewed, the current political climate around policing has police "walking on eggshells" because officers are not being supported by the very communities they have dedicated their lives to protect (Resp. 10). Officers that I spoke to, similar to claims of some American officers, stated they are being unjustifiably accused of racism. Unfair media attention and unfair

\footnotetext{
${ }^{3}$ In the mid-1990s when hate crime emerged as a greater concern of law enforcement, police attention was focused on protecting minority communities from white supremacist and ultra nationalist groups such as the Heritage Front, Ku Klux Klan, the Aryan Resistance Movement, and the Western Guard. Policy was intended to increase levels of acceptance of visible minority communities and advance Canadian multiculturalism (Pitman et al. 1993, Rosen 1994).
} 
criticism from activists have made this problem worse, according to one YRPS officer. "The media has portrayed it [as] these big bad white officers have done this because he's Black or because he's Native" (Resp. 10). Instead, I was told that genuine efforts to safeguard officer safety are being misconstrued and overblown.

You're facing a knife or a gun or a hammer, those are bad days. No one starts their shift, no one sleeps all night and starts off their shift at five [AM] and says, 'Okay, who can I shoot today?' They just want to do their job and clock out and go home. (Resp. 10)

The officer went on to state that for the majority of officers, their actions are guided by genuine desires to serve the public.

No matter what the news shows us of police officers, 99 percent of us go to work in the morning and don't want to shoot anybody and want to get the kitten out of the tree and want to put the rapist away. And we really don't base what we're doing on the person's colour, or on their religion, or on their sex work, or their sexual orientation. (Resp. 10)

Here, the officer evaluates and defends police action based on officer intentions, the importance of taking necessary precautions, and the inherent dangers of police work. The officer depicts deadly police encounters with Black communities as a natural outcome of crime patterns and of criminal behaviour. While negative police encounters are unfortunate, they are at times, unavoidable. Police, therefore, are not responsible for the outcomes of those encounters. This narrative makes possible a re-telling of the story of police encounters that has been the focus of much media attention. Concerns about targeted policing, racial profiling, and racial discrimination are dismissed and, instead, police action is viewed simply as a reflection of "where the crime is happening" (Resp. 8). "We don't choose who is living in that community, we do not choose who calls us for help," an officer told me as he reflected on the turmoil engulfing many American police forces playing out in the international media. "The calls for service," he went on, "are right in the areas of the same community who are protesting us" (Resp. 8). Here, protest action designed to raise awareness about police interactions with members of the public and to demand greater accountability, are recast as obstructions to legitimate police work since police are assumed to have "good" intentions and are committed to doing their job equitably and fairly.

According to this narrative, obstruction to police work by communities or by activist groups is counter-productive for communities themselves because it only works to make communities that already struggle with issues of crime, more unsafe. The same officer recalled a statement made by a fellow officer who commented about the death toll from violent crime in major American cities.

Somebody brought up a really good point to me and if I sat for 1,000 years, I never would have thought of this. Proof that Black lives matter are when the police targeted specific criminal organizations and the murder rate in the violent crime rate dropped. Because when the police were engaged, when the police were targeting criminals, the Black lives were saved because the murder rate was so low. (Resp. 8)

In the above statement, the crime fighting actions of police that targeted "criminal organizations" and "lowered crime rates" are cited to reframe debates about police action. According to this officer, a more appropriate way of understanding police action is through reductions in overall crime rates, which, we are led to believe, is a result of police crime fighting efforts. Even if police action has resulted in the deaths of Black 
people, this narrative suggests the overall effect of police presence in Black communities is a positive one. However, these statements are paradoxical when police action is viewed in context. Many of the policing practices touted for lowering crime rates stopping, questioning and frisking pedestrians; aggressive policing of low-level crime; over-policing of poor and racialized neighbourhoods; and the use of police raids - have had particularly detrimental effects on Black communities and in some cases have cost Black men, women and children their lives. In effect, police save Black lives through many of the same actions that also end Black lives.

I was told that because of protest action the confidence of police officers has been shaken and that officers are withdrawing from high crime areas. "Now that everyone is backing away," an officer stressed, "the murder rate is starting to soar typically in a lot of minority communities, and we are being accused of Black lives not mattering and that is very difficult for a police officer to take" (Resp. 8). The "unjustified" concerns about police action by Black communities have not resulted in greater safety but have actually given rise, according to this officer, to higher crime rates. In effect, communities have become casualties of their own action. Officers suggested that (some) communities needed to understand that they are faced with two choices: they can accept the realities of police work and embrace police presence in their communities, or they can be left to the criminal elements that compromise community safety. Either way, positive policecommunity relations and the power to build bridges between residents and law enforcement are the responsibility of the community - in essence, the police will be there if the community so desires.

Community "resistance" was not only articulated by officers as frustration with diverse communities, it was also discussed as a safety threat. On July $7^{\text {th }}, 2016$, five Dallas police officers were shot and killed by Micah Xavier Johnson, an Afghan War veteran who was reportedly angry over police shootings of unarmed Black men (Karimi et al. 2016). The shooting took place after a peaceful protest demonstrating against the killings of Alton Sterling in Baton Rouge, Louisiana, and Philando Castile in Falcon Heights, Minnesota, whose killing was live-streamed to Facebook. Some within the law enforcement community blamed the death of the Dallas officers on what they saw as the incendiary and divisive rhetoric of the Black Lives Matter movement (Weigel 2016). The same officer spoke about his frustration with the killing of the Dallas officers and told me that events like this only further destabilize police-community relations.

It's maddening for us, as I said, because you watch five police officers get gunned down in Dallas. And what boggles the mind is how the world doesn't see that that would do nothing but again ostracize the police from communities they are trying to protect. And if they weren't starting to get preconceived notions previously, they are now. (Resp. 8)

This officer views communities as agents who choose to alienate themselves from police and, as a result, officers are developing their own biases toward the community. While the violence of law enforcement is viewed as atypical, community "resistance" is having profound effects - effects that communities alone are believed to be responsible for. Due to the tense relationship between police and Black communities in the United States, the officer told me that violent encounters were likely to increase. 
So now I'm not going to be surprised and see those types of shootings increase because the same things that they are protesting they are perpetuating by killing police officers. (Resp. 8)

Resistance to diversity on the part of police becomes a "natural product" of community decisions to "alienate" the police in this account. While police work hard to perform their duties professionally, this account stresses that police are now victims of their own wellmeaning efforts to maintain public safety.

Police victimization becomes a prism through which some officers interpret their own personal experiences and interactions with the public. These officers come to see and interpret their own conflicts with communities in relation to the plight of officers South of the border. Officer frustration and anger are not solely related to protecting policing institutions or defending officers, however. When predominantly white officers speak out against the unfair treatment stemming from protest action, emanating predominantly from Black communities and directed mainly against white officers, criticisms operate as a defence of whiteness in and of itself. In the narrative of the above officer, violence that occurs during some police encounters framed as rare, isolated, and exceptional, in much the same way that the violence of white police officers is imagined as rare and atypical. Implicit in the protest action of the Black Lives Matter Movement is a critique of white supremacy and the way that white advantage, along with Black marginalization, produces and sustains the deaths of Black bodies at the hands of police. While officers criticized protest action as "overblown" and "unnecessary", concerns about systemic racism in the United States (which originally gave rise to the protest action) remained unexamined and unacknowledged in some officer narratives. This is not simply a defence of police action, but an indirect defence of white male police officers, who have been most often implicated in these actions.

Writing about the emergence of "post-racial" discourses in the European context, Lentin (2014) argues that race-neutral discourses that attempt to universalize the experience of racial oppression function as "racism under a different guise" (Lentin 2014, 1404). "Antiwhite" sentiments reconfigured as "anti-police" sentiments in this instance, effectively neutralize claims that police power is wielded disproportionately against some bodies over others. This enforces the notion that racism can now be reversed. We are asked to view (problematic) police interactions as disconnected individual moments unrelated to realities of race and racism. Through these narratives, we are led to believe that (white) police officers are not the problem. Instead, legitimate concerns about public safety and the safety of those who maintain it (police officers) are the only issues that should remain in view.

The Black Lives Matter movement and officer concerns about "negative" media attention on police in the United States serve as a tangible reminder for some officers of the very real danger of diversity when diversity is perceived to have 'gone too far.' In offering up these accounts, officers' defence of the actions of largely white police officers in the United States function not only as a defence of policing institutions but indirectly as a defence of whiteness. Here, the historical and contemporary deployment of police power as violence and as an oppressive mechanism of racial control in the U.S. and Canada, is reconfigured as modern phenomena produced (in the view of some officers) by overblown concerns of institutional racism. 


\section{Conclusion}

In this paper, I examine how hate crime response involves invoking, embracing, and contesting commitments to racial and cultural diversity. Diversity is a core framework for hate crime response in the YRPS. Respect for racial and cultural diversity becomes a method through which police convey the importance of combating hate crime and the dangers hate crime poses to Canadian society. By collaborating with community members, connecting with communities, and building new relationships that allow for two-way communication, police claim to better support those most vulnerable to hate crime. The adoption of diversity as a central framework for hate crime response has the effect of (re)configuring hate as a problem of individual sensibilities and negative interactions. Diversity works to remedy these problems, according to police, by exposing individuals to the customs, traditions, and the cultures of others. While police embrace diversity as a method of hate crime prevention, diversity is also contested by officers engaged in hate crime response. "Examples" of police victimization at the hands of diverse communities or the perception that diverse people refuse to integrate into Canadian life, transforms diversity and diverse communities into something problematic for police and society. The use of diversity to frame institutional commitments and, paradoxically as a lens through which those commitments are questioned, reveals the problematic terrain upon which diversity rests.

\section{References}

Ahmed, S., 2000. Strange Encounters: Embodied Others in Post-Coloniality. New York: Routledge.

Ahmed, S., 2004. The Cultural Politics of Emotion. New York: Routledge.

Ahmed, S., 2012. On Being Included: Racism and Diversity in Institutional Life. Durham: Duke University Press.

Bannerji, H., 2000. The Dark Side of the Nation: Essays on Multiculturalism, Nationalism and Gender. Toronto: Canadian Scholars' Press.

Bell, J., 2002. Policing Hatred: Law Enforcement, Civil Rights and Hate Crime. New York University Press.

Berman, M., 2014. Investigations, outrage follow police chokehold and Eric Garner's death. The Washington Post [online], 21 July. Available from:

https://www.washingtonpost.com/news/postnation/wp/2014/07/21/investigations-outrage-follow-police-chokehold-and-ericgarners-death/ [Accessed 10 September 2020].

Boyd, E., Berk, E., and Hamner, K., 1996. Motivated by Hatred or Prejudice: Categorization of hate-motivated crime in two police divisions. Law $\mathcal{E}$ Society Review [online], 30, 819-850. Available from: https://doi.org/10.2307/3054119 [Accessed 10 September 2020].

Buchanan, L., et al., 2015. What Happened in Ferguson? The New York Times [online], 10 August. Available from: https://www.nytimes.com/interactive/2014/08/13/us/ferguson-missouri-townunder-siege-after-police-shooting.html [Accessed 10 September 2020]. 
Canada, Minister of Justice, 1966. Report to the Minister of Justice of the Special Committee on Hate Propaganda in Canada-Cohen Report. Ottawa: Queen's Printer.

Canadian Multiculturalism Act (R.S.C., 1985, c. 24 (4th Supp.)).

Chakraborti, N., and Garland, J., 2010. Hate Crime: Impact, Causes and Responses. London: Sage.

Chakraborti, N., ed., 2010. Hate Crime: Concepts, Policy, Future Directions. Devon: Willan.

Chan, W., and Chunn, D., 2014. Racialization, Crime, and Criminal Justice in Canada. University of Toronto Press.

Day, R., 1998. Constructing the official Canadian: a genealogy of the mosaic methophor in state policy discourse. Topia [online], vol. 2, 42-66. Available from: https://doi.org/10.3138/topia.2.42 [Accessed 10 September 2020].

Fitzsimmons, E., 2014. Video Shows Cleveland Officer Shot Boy in 2 Seconds. The New York Times [online], 26 November. Available from:

https://www.nytimes.com/2014/11/27/us/video-shows-cleveland-officer-shottamir-rice-2-seconds-after-pulling-up-next-to-him.html [Accessed 10 September 2020].

Griffiths, C.T., Parent, R.B., and Whitelow, B., 2001. Community Policing in Canada. Toronto: Neilson.

Hage, G., 2000. White Nation: Fantasies of White Supremacy within a Multicultural Society. London: Routledge.

Hall, N., 2012. Policing hate crime in London and New York City: Some reflections on the factors influencing effective law enforcement, service provision and public trust and confidence. International Review of Victimology [online], 18(1), 73. Available from: https://doi.org/10.1177/0269758011422477 [Accessed 10 September 2020].

Haque, E., 2012. Multiculturalism within a Bilingual Framework: Language, Race, and Belonging in Canada. University of Toronto Press.

Henry, F., et al., 2017. The Equity Myth: Racialization and Indigeneity at Canadian Universities. Vancouver/Toronto: UBC Press.

Iganski, P., ed., 2002. The Hate Debate: Should Hate Be Punished as a Crime? London: Profile Books.

Jiwani, Y., 2011. Hierarchies of Worthiness: Women and Victimhood in Canadian Media. Briarpatch [online], 6 May. Available from: https://briarpatchmagazine.com/articles/view/hierarchies-of-worthiness [Accessed 10 September 2020].

Karimi, F., Shoichet, C.E., and Ellis, R., 2016. Dallas Sniper Attack: 5 Officers Killed, Suspect Identified. CNN [online], 9 July. Available from: https://www.cnn.com/2016/07/08/us/philando-castile-alton-sterlingprotests/index.html [Accessed 10 September 2020].

Kazarian, S., et al., 2007. Diversity Issues in Law Enforcement. Toronto: Emond. 
Lentin, A., 2014. Post-race, post politics: the paradoxical rise of culture after multiculturalism. Ethnic and Racial Studies [online],37(8), 1268-1285. Available from: https://doi.org/10.1080/01419870.2012.664278 [Accessed 10 September 2020].

Mackey, E., 2002. The House of Difference: Cultural Politics and National Identity in Canada. University of Toronto Press.

O'Shea, K., 2016. Walter Scott shooting: Officer said his mind was like "spaghetti". CNN [online], 30 November. Available from:

https://www.cnn.com/2016/11/29/us/michael-slager-murder-trial-walterscott/index.html [Accessed 10 September 2020].

Ontario Police College, 2007. Responding to Hate Crimes: An Ontario Police Officer's Guide to Investigation and Prevention [online]. Toronto: Ontario Police College. Available from: http://hdl.handle.net/20.500.12389/20235 [Accessed 10 September 2020].

Perry, B., 2001. In the Name of Hate: Understanding Hate Crimes. New York: Routledge.

Pitman, R., Russell, J., and Burbach, D., 1993. Report on Hate Group Activity in Ontario Environmental Scan. Solicitor General Canada, Ontario Regional Office.

Police Services Act, R.S.O. 1990.

Razack, S., 2008. Casting Out: The Eviction of Muslims from Western Law and Politics. University of Toronto Press.

Roberts, J., and Hastings, A., 2001. Sentencing in Cases of Hate-Motivated Crime: An Analysis of Subparagraph 718.2(a)(i) of the Criminal Code. Queen's Law Journal, 27, 93-128.

Rosen, P., 1994. Hate Propaganda. Ottawa: Library of Parliament Research Branch.

Rowe, M., 2012. Policing, Race and Racism. London: Routledge.

Shaffer, M., 1995. Criminal Responses to Hate-Motivated Violence: Is Bill C-41Tough Enough? McGill Law Journal, 41, 200-251.

Statistics Canada, 2016. Census Profile: York, Regional Municipality [Census Subdivision] [online]. Ottawa. Available from: http://www12.statcan.gc.ca/censusrecensement/2016/dp$\mathrm{pd} /$ prof/details/page.cfm?Lang=E\&Geo1=CD\&Code1=3519\&Geo2=PR\&Code2 $=35$ \&Data $=$ Count\&SearchText=York\&SearchType=Begins\&SearchPR=01\&B1=Populat ion\&TABID=3 [Accessed 11 August 2018].

Stout, B., 2010. Equality and Diversity in Policing. Exeter: Learning Matters.

Tator, C., and Henry, F., 2006. The Dominant Discourses of White Public Authorities: Narratives of Denial, Deflection, and Oppression. In: C. Tator and F. Henry, Racial Profiling in Canada: Challenging the Myth of a "Few Bad Apples". Toronto University Press, 123-150.

Thobani, S., 2007. Exalted Subjects: Studies in the Making of Race and Nation in Canada. University of Toronto.

Tilley, N., 2003. Community Policing, Problem-oriented Policing and Intelligence led Policing. In: T. Newburn, ed., Handbook of Policing. Compton: Willan, 311-339. 
Toronto Police Service, no date. Community Consultative Process [online]. Available from: http://www.torontopolice.on.ca/community/ccc.php [Accessed 10 September 2020].

Weigel, D., 2016. Texas Republicans blame Black Lives Matter for Shooting of Dallas Police. The Washington Post [online], 8 July. Available from: https://www.washingtonpost.com/news/post-politics/wp/2016/07/08/texasrepublicans-blame-black-lives-matter-for-shooting-of-dallaspolice/?noredirect=on\&utm term=.ba3dff3b90eb [Accessed 10 September 2020].

York Regional Police Service, 2016a. Annual Statistical Report. Aurora: York Regional Police.

York Regional Police Service, 2016b. Diversity, Equity and Inclusion [online]. Aurora: York Regional Police. Available from: https://www.yrp.ca/en/about/DiversityEquity-and-Inclusion.asp? mid =336 [Accessed 10 September 2020].

York Regional Police Service, 2017. Annual Statistical Report. Aurora: York Regional Police.

York Regional Police Service, 2018. Annual Statistical Report. Aurora: York Regional Police. 